\title{
Plasma cortisol levels in malnourished children with and without superimposed acute stress
}

\author{
R. B. PAISEY, MARIELENA ANGERS, and S. FRENK \\ From Hospital de Pediatria, CMN., Mexico City, Mexico
}

\begin{abstract}
Paisey, R. B., Angers, M., and Frenk, S. (1973). Archives of Disease in Childhood, 48, 714. Plasma cortisol levels in malnourished children with and without superimposed acute stress. Plasma cortisol levels were measured in 13 children with marasmus, in 7 with kwashiorkor, and in 24 normal children. Cortisol levels in the malnourished children did not differ from those of the normal group, either before or after 15 or 30 days of treatment, unless there was superimposed acute stress. Stress caused by complications such as hypoglycaemia, infection, hypothermia, or acidosis led to raised plasma cortisol levels.
\end{abstract}

Various biochemical abnormalities have been found in children suffering from protein-calorie malnutrition (Abassy et al., 1967; Becker et al., 1971; McCance, 1971). In children at the marasmic end of the spectrum, serum albumin, glucose tolerance test, haemoglobin, and haematocrit have been found to be normal (McCance, 1971), with low blood glucose levels. At the other extreme, children suffering from kwashiorkor have been shown to have low serum albumin and blood glucose, high plasma cortisol and free fatty acids, with impaired glucose tolerance tests. In both kinds of malnutrition, raised plasma cortisol levels have been reported (Rao, Srikantia, and Gopalan, 1968). Assessment of these children can be based on the presence of oedema, skin and hair changes, and hepatomegaly, together with measurements of serum albumin (McLaren, 1968).

Our intention in this study was to correlate plasma cortisol levels in kwashiorkor and marasmus, on admission and during treatment, with the presence or absence of additional stresses resulting from complications such as infection, hypoglycaemia, hypothermia, and acidosis (Alleyne and Young, 1966; Brenton, Brown, and Wharton, 1967; Najjar and Bitar, 1967; Wharton, 1970).

\section{Methods}

Plasma cortisol levels were measured in 24 normal children between 6 and 24 months of age, and in 20 sick children all of whom were admitted to hospital with grade 3 malnutrition. Grade 3 marasmus was diagnosed when the infant exhibited $40 \%$ or greater deficit in ideal weight for age, lack of oedema or skin changes, absence of

Received 25 January 1973. subcutaneous adipose tissue, diminution in muscle mass, and normal serum albumin. 13 of the children fell into this category. The remaining 7 were judged to have grade 3 malnutrition with kwashiorkor, on the basis of $30 \%$ or greater deficit in ideal weight for age, generalized oedema, desquamating dry plaques of skin with hyperand hypopigmentation, low serum albumin, and unusually fair, friable, and scanty hair.

Blood samples were taken on the day of admission, and on the 15th and 30th days of treatment; thorough physical examinations were also carried out at the times of blood sampling.

Cortisol. Plasma cortisol levels were measured by a modification of the competitive protein binding technique described by Murphy, Engelberg, and Pattee (1963) in which $0.1 \mathrm{ml}$ aliquots of plasma were measured in duplicate and, where possible, in quadruplicate.

\section{Results}

Table I shows the cortisol levels found in 13 marasmic children. The marasmic children with the additional stress due to complications had cortisol levels above the normal range, whereas those with uncomplicated marasmus had normal levels.

Table II similarly shows that among 7 kwashiorkor children, only those with additional stress due to complications showed cortisol levels above the normal range.

\section{Discussion}

The normal range of plasma cortisol levels in children between the ages of 6 and 24 months was found to be 5.5 to $20 \mu \mathrm{g} / 100 \mathrm{ml}$ with a mean of $12 \cdot 9 \pm 2 \cdot 2$ (SD) $\mu \mathrm{g} / 100 \mathrm{ml}$. The values were distributed such that $95 \%$ of cortisol levels in 
Plasma cortisol levels in malnourished children with and without superimposed acute stress 715 TABLE I

Effect of superimposed stress on plasma cortisol levels of children with marasmus on days 1, 15, and 30

\begin{tabular}{|c|c|c|c|c|c|c|c|}
\hline \multirow{2}{*}{ Case no. } & \multicolumn{5}{|c|}{ Acute stress } & \multicolumn{2}{|c|}{ No stress } \\
\hline & $\begin{array}{c}\text { Cortisol } \\
(\mu \mathrm{g} / 100 \mathrm{ml})\end{array}$ & $\begin{array}{c}\text { Glucose } \\
(\mathrm{mg} / 100 \mathrm{ml})\end{array}$ & $p H$ & $\begin{array}{l}\text { Rectal temp. } \\
\left({ }^{\circ} \mathrm{C}\right)\end{array}$ & Stress & Case no. & $\begin{array}{c}\text { Cortisol } \\
(\mu \mathrm{g} / 100 \mathrm{ml})\end{array}$ \\
\hline $\begin{array}{c}\text { Day } 1 \\
4 \\
7 \\
9 \\
10 \\
11 \\
\text { mean } \pm \text { SD }\end{array}$ & $\begin{array}{c}42 \cdot 0 \\
23 \cdot 5 \\
28 \cdot 0 \\
23 \cdot 5 \\
50 \cdot 0 \\
33 \cdot 4 \pm 12 \cdot 0\end{array}$ & $\begin{array}{l}47 \\
70 \\
47 \\
47 \\
17 \\
\end{array}$ & $\begin{array}{l}7 \cdot 19 \\
7 \cdot 22 \\
7 \cdot 30 \\
7 \cdot 38 \\
7 \cdot 20\end{array}$ & $\begin{array}{l}36 \cdot 5 \\
37 \cdot 0 \\
37 \cdot 5 \\
36 \cdot 6 \\
36 \cdot 8\end{array}$ & $\begin{array}{l}\text { Gastroenteritis } \\
\text { Acidosis } \\
\text { Gasiroenteritis } \\
\text { Otitis media } \\
\text { Hypoglycaemia }\end{array}$ & $\begin{array}{c}\text { Day } 1 \\
1 \\
2 \\
3 \\
5 \\
6 \\
8 \\
12 \\
13 \\
\text { mean } \pm \text { SD }\end{array}$ & $\begin{array}{c}13 \cdot 75 \\
12 \cdot 5 \\
7 \cdot 5 \\
13 \cdot 0 \\
12 \cdot 0 \\
11 \cdot 5 \\
10 \cdot 0 \\
18 \cdot 0 \\
12 \cdot 3 \pm 3 \cdot 0\end{array}$ \\
\hline $\begin{array}{c}\text { Day } 15 \\
4 \\
6 \\
8 \\
11 \\
12 \\
\text { mean } \pm S D\end{array}$ & $\begin{array}{c}47 \cdot 0 \\
51 \cdot 0 \\
32 \cdot 0 \\
30 \cdot 5 \\
33 \cdot 0 \\
38 \cdot 7 \pm 9 \cdot 5\end{array}$ & $\begin{array}{l}29 \\
25 \\
72 \\
80 \\
30\end{array}$ & $\begin{array}{l}7 \cdot 32 \\
7 \cdot 34 \\
7 \cdot 39 \\
7 \cdot 38 \\
7 \cdot 33\end{array}$ & $\begin{array}{l}36 \cdot 5 \\
36 \cdot 7 \\
36 \cdot 8 \\
36 \cdot 5 \\
36 \cdot 5\end{array}$ & $\begin{array}{l}\text { Hypoglycaemia } \\
\text { Hypoglycaemia } \\
\text { Gastroenteritis } \\
\text { Pneumonia } \\
\text { Hypoglycaemia }\end{array}$ & $\begin{array}{c}\text { Day } 15 \\
1 \\
2 \\
3 \\
5 \\
7 \\
9 \\
10 \\
\text { mean } \pm S D\end{array}$ & $\begin{array}{c}13 \cdot 8 \\
8 \cdot 0 \\
11 \cdot 0 \\
11 \cdot 0 \\
17 \cdot 0 \\
11 \cdot 5 \\
12 \cdot 5 \\
12 \cdot 1 \pm 2 \cdot 8\end{array}$ \\
\hline $\begin{array}{c}\text { Day } 30 \\
1 \\
4 \\
8 \\
12 \\
\text { mean } \pm S D\end{array}$ & $\begin{array}{c}42 \cdot 0 \\
35 \cdot 0 \\
30 \cdot 0 \\
25 \cdot 0 \\
33 \cdot 0 \pm 2 \cdot 40\end{array}$ & $\begin{array}{l}39 \\
42 \\
59 \\
35\end{array}$ & $\begin{array}{l}7 \cdot 30 \\
7 \cdot 24 \\
7 \cdot 36 \\
7 \cdot 32\end{array}$ & $\begin{array}{l}36 \cdot 8 \\
36 \cdot 5 \\
36 \cdot 5 \\
36 \cdot 7\end{array}$ & $\begin{array}{l}\text { Gastroenteritis } \\
\text { Acidosis } \\
\text { Measles } \\
\text { Gastroenteritis }\end{array}$ & $\begin{array}{c}\text { Day } 30 \\
2 \\
3 \\
6 \\
7 \\
9 \\
10 \\
11 \\
\text { mean } \pm S D\end{array}$ & $\begin{array}{c}13 \cdot 0 \\
10 \cdot 0 \\
13 \cdot 5 \\
11 \cdot 5 \\
11 \cdot 0 \\
10 \cdot 0 \\
17 \cdot 0 \\
12 \cdot 3 \pm 2 \cdot 5\end{array}$ \\
\hline
\end{tabular}

Note: Plasma cortisol for 24 normal controls $12 \cdot 9 \pm 2 \cdot 2$ (SD).

TABLE II

Effect of superimposed stress on plasma cortisol levels of children with kwashiorkor on days 1, 15, and 30

\begin{tabular}{|c|c|c|c|c|c|c|c|}
\hline \multirow{2}{*}{ Case no. } & \multicolumn{5}{|c|}{ Acute stress } & \multicolumn{2}{|c|}{ No stress } \\
\hline & $\begin{array}{c}\text { Cortisol } \\
(\mu \mathrm{g} / 100 \mathrm{ml})\end{array}$ & $\begin{array}{c}\text { Glucose } \\
(\mathrm{mg} / 100 \mathrm{ml})\end{array}$ & $\mathbf{p H}$ & $\begin{array}{l}\text { Rectal temp. } \\
\left({ }^{\circ} \mathrm{C}\right)\end{array}$ & Stress & Case no. & $\begin{array}{c}\text { Cortisol } \\
(\mu \mathrm{g} / 100 \mathrm{ml})\end{array}$ \\
\hline $\begin{array}{c}\text { Day } 1 \\
3 \\
7 \\
10 \\
17 \\
\text { mean } \pm \text { SD }\end{array}$ & $\begin{array}{c}26 \cdot 0 \\
27 \cdot 0 \\
50 \cdot 0 \\
25 \cdot 0 \\
32 \cdot 0 \pm 12 \cdot 0\end{array}$ & $\begin{array}{l}54 \\
60 \\
27 \\
42\end{array}$ & $\begin{array}{l}7 \cdot 41 \\
7 \cdot 45 \\
7 \cdot 34 \\
7 \cdot 25\end{array}$ & $\begin{array}{l}37 \cdot 6 \\
36 \cdot 0 \\
36 \cdot 8 \\
36 \cdot 5\end{array}$ & $\begin{array}{l}\text { Gastroenteritis } \\
\text { Bronchitis } \\
\text { Gastroenteritis } \\
\text { Acidosis }\end{array}$ & $\begin{array}{c}\text { Day } 1 \\
1 \\
2 \\
8\end{array}$ & $\begin{array}{l}18 \cdot 5 \\
13 \cdot 0 \\
16 \cdot 25\end{array}$ \\
\hline $\begin{array}{l}\text { Day } 15 \\
\text { None }\end{array}$ & & & & & & $\begin{array}{c}\text { Day } 15 \\
1 \\
2 \\
3 \\
7 \\
8 \\
17 \\
\text { mean } \pm S D\end{array}$ & $\begin{array}{c}14 \cdot 0 \\
15 \cdot 0 \\
15 \cdot 5 \\
10 \cdot 5 \\
9 \cdot 0 \\
16 \cdot 0 \\
13 \cdot 3 \pm 2 \cdot 9\end{array}$ \\
\hline $\begin{array}{c}\text { Day } 30 \\
17\end{array}$ & $16 \cdot 0$ & 47 & $7 \cdot 32$ & $36 \cdot 8$ & $\begin{array}{l}\text { Infected napkin } \\
\text { rash }\end{array}$ & $\begin{array}{c}\text { Day } 30 \\
1 \\
2 \\
3 \\
7 \\
8 \\
\text { mean } \pm \text { SD }\end{array}$ & $\begin{array}{c}13 \cdot 5 \\
10 \cdot 7 \\
21 \cdot 0 \\
10 \cdot 4 \\
16 \cdot 5 \\
14 \cdot 4 \pm 4 \cdot 4\end{array}$ \\
\hline
\end{tabular}

Note: Plasma cortisol for 24 normal controls $12 \cdot 9 \pm 2 \cdot 2$ (SD). 
normal children of this age group would fall between $7 \cdot 6$ and $18 \cdot 1 \mu \mathrm{g} / 100 \mathrm{ml}$.

From Table I it can be seen that of the 13 children suffering from marasmus, those without any acute stress had cortisol levels within these $95 \%$ confidence limits at days 1, 15, and 30. However, those marasmic children suffering additional acute stress (infection, hypoglycaemia, hypothermia, or acidosis), whether on day 1 or after 15 or 30 days of treatment, all showed plasma cortisol levels between 23.5 and $51.0 \mu \mathrm{g} / 100 \mathrm{ml}$, i.e. well above the normal range. Some children, for example Case 1, had a plasma cortisol level within normal limits on admission and after 15 days of treatment, but a much higher level $(42 \mu \mathrm{g} / 100 \mathrm{ml})$ after 30 days of treatment when he contracted severe gastroenteritis.

A similar pattern of results is seen among the smaller number of children suffering from kwashiorkor. It is notable that Case 10 with kwashiorkor died from gastroenteritis with which he was admitted, despite producing a plasma cortisol of $50 \mu \mathrm{g} / 100 \mathrm{ml}$.

There thus appears to be no impairment of adrenocortical function in kwashiorkor or marasmus, however severe, as such children respond to infection, hypoglycaemia, hypothermia, and acidosis with raised plasma levels of cortisol. Further, when these children are not suffering from any acute stress over and above their malnutrition, their plasma cortisol levels remain within normal limits.

Protein-calorie malnutrition is well known to be multifactorial in its aetiology, and it is suggested that variations in plasma cortisol levels in this spectrum of conditions is merely a biochemical marker of this multiple aetiology, including infective processes, and of complications such as hypoglycaemia.

We thank Dr. Luengas and the nurses on the nutrition ward in Hospital de Pediatria, the Chemical Pathology Laboratory of the hospital, and Drs. Stimmler and Baker of Guy's Hospital, London, for their help.

\section{REFBRENCES}

Abassy, A. S., Mikhail, M., Zeitoun, M. M., and Ragab, M. (1967), The suprarenal cortical function as measured by the plasma 17-hydroxycorticosteroid level in malnourished children. fournal of Tropical Pediatrics and African Child Health, 13, 155.

Alleyne, G. A. O., and Young, V. H. (1966). Adrenal function in malnutrition. Lancet, 1,911.

Becker, D. J., Pimstone, B. L., Hansen, J. D. L., and Hendrichs, S. (1971). Insulin secretion in protein-calorie malnutrition. Diabetes, 20, 542.

Brenton, D. P., Brown, R. E., and Wharton, B. A. (1967). Hypothermia in kwashiorkor. Lancet, 1,410 .

McCance, R. A. (1971). Malnutrition in the children of underdeveloped countries. In Recent Advances in Paediatrics, 4th ed., p. 479. Ed. by D. Gairdner and D. Hull. Churchill, London.

McLaren, D. S. (1968). Defining marasmus and kwashiorkor. Nutrition Reviezs, 26, 256.

Murphy, B. P., Engelberg, W., and Pattee, C. J. (1963). A simple method for the determination of plasma corticoids. Fournal of Clinical Endocrinology, 23, 293.

Najiar, S. S., and Bitar, J. G. (1967). Adrenal cortex in marasmic children. Archives of Disease in Childhood, 42, 657.

Rao, K. S. J., Srikantia, S. G., and Gopalan, C. (1968). Plasma cortisol levels in protein-calorie malnutrition. Archives of Disease in Childhood, 43, 365.

Wharton, B. (1970). Hypoglycaemia in children with kwashiorkor. Lancet, $1,171$.

Correspondence to Dr. R. B. Paisey, East Wing: Guy's Hospital, London S.E.1. 